\title{
The role of invertebrates in the diet, growth and survival of red grouse (Lagopus lagopus scoticus) chicks
}

\author{
Park, K.J. ${ }^{1}$, Robertson, P.A. ${ }^{2}$, Campbell, S.T. ${ }^{3}$, Foster, R. ${ }^{3}$, Russell, Z.M. ${ }^{1}$, Newborn, D. ${ }^{3}$ \& Hudson, \\ P.J. ${ }^{1}$ \\ ${ }^{1}$ Department of Biological Sciences, University of Stirling, Stirling FK9 4LA \\ ${ }^{2}$ Central Science Laboratory, Sand Hutton, York YO41 1LZ \\ ${ }^{3}$ The Game Conservancy Trust, Crubenmore Lodge, Newtonmore, Inveness-shire PH20 1 BE
}

Corresponding Author: Kirsty J. Park

$\begin{array}{ll}\text { Address } & \text { Department of Biological Sciences, University of Stirling, Stirling FK9 4LA } \\ \text { Tel } & 01786467799 \\ \text { Fax } & 01786464994 \\ \text { Email } & \text { k.j.park@stir.ac.uk }\end{array}$

Running Head: Red grouse chick growth and survival

Keywords: red grouse, chick, invertebrate, diet, survival 


\section{ABSTRACT}

The role of diet on the growth, survival and movement of red grouse chicks was examined. We compared two areas of moorland in Scotland; a dry heath with a low density of red grouse and poor chick survival and a wetter heath/bog with relatively higher red grouse numbers and higher rates of chick survival. There were no differences in clutch size, or the proportion of eggs hatching between the two moors but brood survival was significantly lower on the dry heath. Radiotagged hens with broods were monitored during the first 12 days following hatching, the chicks captured, weighed and faecal samples collected. Invertebrate samples were collected within brood feeding ranges. Analysis of chick faeces was used to identify dietary components. Heather comprised the major dietary component on both moors. Invertebrates formed a higher component of diet on the wet moor, and this was positively correlated with growth rates, which in turn were positively correlated with chick survival. We present data from an experiment carried out in 1982, in which chicks showed higher growth rates with increasing insect availability. We also show that broods in which all the chicks survived (4-10 days) had smaller home range areas than broods in which some of the chicks died during this period. We suggest that the differences in chick survival between the two populations was due to variations in the abundance of invertebrates, particularly Tipulids. The protein provided by a high invertebrate component in the diet is, therefore, an important determinant of young red grouse chick growth and survival in some areas.

\section{INTRODUCTION}

Red grouse (Lagopus lagopus scoticus) are restricted to the heather Calluna vulgaris uplands of Britain, an internationally scarce and valuable habitat type (Thompson et al., 1995). It is a bird of economic importance as a quarry species and has been the subject of several long-term studies investigating their ecology, population dynamics and behaviour (Jenkins, Watson \& Miller, 1963, 1967; Watson \& Moss, 1979; Moss \& Watson, 1985; Hudson, 1986a; Hudson et al., 1997; Hudson, 1992; Watson et al., 1994). Some of these studies have suggested that variations in chick survival 
between sites influences productivity, and others that chick survival within a site may play a role in year to year changes in red grouse numbers.

There is evidence suggesting that chick survival is influenced by the intrinsic quality of the hen together with food availability and weather experienced before laying (Jenkins et al., 1963, 1967; Moss, Watson \& Parr, 1975; Moss et al., 1981). Chick survival can also be influenced by the intensity of maternal infection with the caecal nematode Trichostrongylus tenuis (Hudson, 1986b). Diseases such as louping ill can cause direct chick mortality at three to four weeks of age, although this has a limited distribution within this species’ range (Hudson et al., 1997). In some areas predation, by species such as the hen harrier (Circus cyanus), can also reduce chick survival rates (Redpath, 1991, Redpath \& Thirgood, 1997). A protein-rich diet has been shown to influence the early survival prospects of other gamebirds and these proteins are typically obtained through invertebrates (Southwood \& Cross, 1969; Hill, 1985; Rands, 1985; Potts, 1986; Hill \& Robertson, 1988). Although young red grouse are known to include invertebrates in their diet (Grimshaw, 1911, Butterfield \& Coulson, 1975; Hudson, 1986a), heather shoots make up a high proportion of diet by volume. There has been much debate in the past over the importance of invertebrates in red grouse chick diet. Previous studies have found that insects formed only a small proportion by weight of the red grouse chick diet (Savory, 1977) and that there is a high vegetative component in the chick diet of both red grouse and the closely related willow grouse (Lagopus lagopus) (Pullianen \& Eskonen, 1982), suggesting that invertebrates are relatively unimportant for growth and survival (Savory, 1977). More recently, however, there has been increasing evidence that, particularly in summer, invertebrates are important for some granivorous birds, for whom the bulk of the diet consists of seeds and plant material (Potts, 1986; Wilson et al., 1999). 
Despite the large volume of research published on this species there is no evidence from free living red grouse on which to assess the effects of diet, including its invertebrate component, on chick survival. Hudson (1986a) followed the movements and habitat selection of broods in Yorkshire. He found that they concentrated their activity in bog flushes which were particularly rich in those insects identified from the droppings. He also found that chick survival was associated with abundance of insect remains in the droppings of these chicks, although this relationship varied between years. Wet, boggy moorland has been shown to contain higher densities of certain invertebrates sampled by pitfall traps, particularly Tipulids, than dry heaths (Butterfield \& Coulson, 1975; Savory, 1977). Tipulids are poor fliers and are usually found resting on vegetation, which presumably makes them more vulnerable to predation by red grouse (Butterfield \& Coulson, 1975). In this paper we compare red grouse chick growth, survival and diet during the first 10 days after hatching between two moors; a dry heath and a wetter area of blanket bog. We examine differences in insect availability between the two moors, and present data from an experiment carried out in 1982 which directly tests the effect of invertebrates in the diet upon chick growth and survival. Management options to increase chick survival rates on heather moorland are suggested.

\section{MATERIALS AND METHODS}

\section{Study areas and long-term monitoring}

Two moors were used for this study, South Drumochter and Ralia, both in Southern Inverness-shire in the Scottish highlands. These moors provide contrasting habitats and red grouse densities. Ralia is a relatively flat, dry heath of $280 \mathrm{~m}$ altitude at its central point, South Drumochter (henceforth referred to as Drumochter) is a higher (central point altitude, $480 \mathrm{~m}$ ), wet heath with patches of blanket bog. Red grouse counts have been conducted on both moors since 1985 (Drumochter) and 1986 (Ralia). On each moor red grouse in two $1 \mathrm{~km}^{2}$ blocks were counted in April and again in July with pointing dogs to obtain estimates of pre-breeding and post-breeding populations (Jenkins et al., 
1963). Repeated-measures ANOVAs were used to analyse grouse count data (1986 - 1997). Mean numbers of birds from the two counts were used for the purpose of analysis. These data were used to calculate mean July brood size (when chicks are approximately six to eight weeks old) per estate against which to compare Ralia and Drumochter. Similar counts were conducted on 33 other managed red grouse moors in Scotland for at least five years per site over the period 1985-1996. Nests were also located on Ralia and Drumochter each year through a combination of searches with pointing dogs and following adult hens fitted with radio-transmitters. A sample of adult females shot after the breeding season (August to December) between 1988 and 1996 on both moors were inspected for infections of T. tenuis and for the presence of the louping ill antibody.

\section{Radiotelemetry of broods}

Females were captured by night lamping during the winter and early spring on each moor (Hudson \& Newborn, 1995). Hens were fitted with small necklace radio transmitters similar to those used by Thirgood et al. (1995) who found they had no effect on survival or breeding success. Chick growth and survival was monitored in broods produced by 87 hens between 1994 and 1997. Each hen was located weekly during from between late autumn to late winter (October to February) until nesting. Absence of the hen during incubation allowed clutch size to be determined, and the incubating hens were then located every two days to determine hatch date. Hatch success was assessed by examining the nests for shells, unhatched eggs and dead chicks. The intensity with which each brood was then monitored varied depending on accessibility and the number of broods active at any one time. We attempted to capture broods twice during the first 12 days after hatching; once at 4 days (range 3-6), and again at 10 days (range 9-12) using pointing dogs. The range of catch dates was due to weather conditions (chicks were not disturbed during adverse conditions). For the purposes of analysis these are referred to as 4 day and 10 day captures. Body mass and wing length were recorded for each chick, and averaged per brood. Individual chicks were down clipped at first catch so that they could 
be identified upon re-capture, and once large enough (> $30 \mathrm{~g}$ ) were fitted with patagial tags. Diet was assessed via faecal samples obtained from chicks during handling. Invertebrate occurrence in the faeces (dietary invertebrates) was corrected for the number of heather bracts found in the same sample, and is quoted as the number of invertebrates per 100 heather bracts (Hudson, 1986a). Between late May and early July standardised sweep net samples for invertebrates were taken in the area occupied by the brood if the vegetation was not waterlogged.

\section{Home range analysis}

Home range area for broods with more than 15 radio locations (fixes), was calculated during the first 12 days after hatching. The number of fixes varied from 17 to 30 with a median value of 23.5. All home range estimates are sensitive to sample size (Robertson et al., 1998), so home ranges here were standardised to 17 fixes by use of a bootstrapping procedure. For broods with more than 17 fixes the bivariate normal ellipse was recalculated (Jennrich \& Turner, 1969) for random selections of 17 fixes (for the calculation of mean values 30 replicates was considered sufficient), and the mean value calculated. This allows home range areas to be corrected for differences in the number of fixes between broods.

\section{Chick growth and survival experiment}

In addition to data collected in the field, we present data from an experiment carried out in 1982 which directly tests the effect of invertebrate availability on red grouse chick growth and survival (Hudson, 1986a). Three aviaries were erected in a draught free room with brooder lamps. A total of 16 eggs were removed from nests of red grouse on managed grouse moors and hatched in an incubator. Chicks from the same broods were split between the three treatments ensuring that there were no differences in the genetic constitution or quality of chicks between the groups. One group of chicks had access to water and young heather, which was replaced daily and sprayed regularly with 
water to keep it fresh. The heather provided was not inspected for invertebrates, so chicks in this group may have had access to a very small supply of invertebrates. The other two groups were maintained under identical conditions, but in addition one was given a limited supply of invertebrates (mostly Tipulids) collected from a nearby red grouse moor, and the other provided with invertebrates ad lib. Chicks were weighed daily until ten days after hatching. A further three chicks were added to treatment groups two (one chick) and three (two chicks) on day three; consequently the analysis is confined to data collected between days three and ten.

Data were transformed to achieve normality and homoscedasticity, and were analysed using MINITAB release 12.1 and STATISTICA release 5.5. Where the assumptions of normality were violated, non-parametric methods were used. Unless otherwise stated General Linear Models were used for analyses, and data are presented as means \pm s.e. or medians and interquartile ranges (Q1Q3).

\section{RESULTS}

\section{Comparison of study areas}

We tested for differences between the two moors in red grouse density in April (1986-1997) and in July (1986-1996), number of broods produced, and the size of clutches and broods (Table 1). Year was included in this analysis and had no significant relationship with density in April, although there were differences between years in density for July. Drumochter contained significantly more adults per $\mathrm{km}^{2}$ in April $(32.5 \pm 2.3)$ than Ralia $(12.9 \pm 1.4)$, and higher numbers of young and adults per $\mathrm{km}^{2}$ in July (101.5, Q1-Q3: 58.5 - 201.0) than Ralia (20.2, Q1-Q3: 15.3 - 42.6). Significantly more broods were produced on Drumochter (13.0, Q1-Q3: 7.5 - 20.0) than on Ralia (4.2, Q1-Q3: 2.6 5.9). A total of 243 nests (Drumochter $n=129$, Ralia $n=114$ ) were located from 1986 to 1996 . There were no significant differences between size of clutches on Drumochter $(8.0 \pm 0.2)$ and those on 
Ralia (8.6 \pm 0.1 ), although there were significant differences between years (Table 1$)$. There was also no difference between the proportion of eggs hatching (Mann-Whitney $W_{105,100}=10591.0$, NS) on the two moors, excluding those clutches where no eggs hatched. In July, however, when the chicks are approximately six to eight weeks old, mean brood sizes were significantly lower on Ralia (3.5, Q1-Q3: 3.0 - 4.7) than on Drumochter (5.6, Q1-Q3: 4.6 - 6.2; Table 1), indicating that brood survival was lower on Ralia. Comparing these July brood sizes to those obtained from a sample of 33 other managed red grouse moors in Scotland (Fig. 1) identified Ralia as producing amongst the smallest broods and Drumochter amongst the largest.

Table 1 here

Fig. 1 here

Post-mortem assessment of Trichostrongylus tenuis numbers in shot adult females showed that median worm burdens were significantly higher in birds on Drumochter (520.0, Q1-Q3: 75.0 1508.0) than birds on Ralia (19.0, Q1-Q3: 0.0 - 85.5) (Mann-Whitney $W_{105,34}=8457.5, P<0.0001$ ). Median body mass of shot adult females on Drumochter was 600g (Q1-Q3: 556.3 - 648.8) and on Ralia was 575g (Q1-Q3: 550.0 - 626.3). There was no significant difference in female body mass between the two moors (Mann-Whitney $W_{104,34}=7465.0$, NS). Examination of sera from young birds found no evidence that birds had developed immunity to louping ill on either moor.

\section{Diet analysis}

A total of 62 faecal samples (Drumochter $n=40$, Ralia $n=22$ ) were collected from different broods. The occurrence of invertebrates and plant matter are presented in Table 2. Of 155 invertebrates identified from samples on Ralia, weevils (Curculionidae) were the most frequent items (48\% by 
number), followed by crane flies (Tipulidae) 20\%, Staphalinidae sp. (8\%) and larval Symphyta (6\%). On Drumochter, of 1,971 invertebrates identified, Tipulidae were numerically dominant (73\%), followed by Chironomidae (24\%). No other group comprised more than $1 \%$ of the total. With the exception of two Drumochter samples which contained large quantities of unidentified leaf material, the majority of vegetation in the diet comprised heather, its seeds and flowers, sundew heads and moss capsules. There were 44 faecal samples from 1996 (Drumochter $n=37$, Ralia $n=7$ ) for which the exact age of the chicks (between 3 and 12 days) was known. Chick faeces from Drumochter contained a significantly higher proportion of invertebrates per 100 bracts (5.0, Q1-Q3: 2.3 - 12.3) than did chicks from Ralia (2.4, Q1-Q3: 0.6 - 5.6) $\left(F_{1,41}=5.11, P<0.05\right)$. There were no significant differences between years, and effect of chick age $\left(F_{1,41}=0.26\right.$, NS) was controlled for by including exact age in the model.

Table 2 here

\section{Invertebrate availability}

Drumochter sweep samples (1995 and 1996) contained a significantly higher number of insects per sample (35.5, Q1-Q3: 17.0 - 138.3) than did samples from Ralia (9.5, Q1-Q3: 1.8 - 21.3) $\left(F_{1,36}=\right.$ 14.26, $P=0.001)$. A significant interaction between moor and year showed that there was a decrease in the number of insects sampled on Ralia but not on Drumochter in $1996\left(F_{1,36}=5.31, P<0.05\right)$. The difference between the two moors was largely due to differences in the numbers of Diptera (Drumochter 30.0, Q1-Q3: 13.0 - 127.0 per sample; Ralia 4.0, Q1-Q3: 0.0 - 6.3). Although relatively few Tipulidae were sampled by sweep netting on either moor they were seven times as abundant on Drumochter (Drumochter 0.0, Q1-Q3: 0.0 - 1.0) per sample; Ralia 0.0, Q1-Q3: 0.0 - 0.0), other Diptera were 22 times as abundant. Excluding Diptera there were no significant differences in invertebrate numbers per sweep between the moors $\left(F_{1,36}=0.01\right.$, NS), although again a significant 
interaction between moor and year showed that there was a decrease in the number of insects (excluding Diptera) sampled on Ralia but not on Drumochter in $1996\left(F_{1,36}=8.15, P<0.01\right)$.

\section{Chick Growth Rates}

A total of 40 broods (Drumochter $n=31$, Ralia $n=9$ ) provided data on mean brood body mass and wing length. Exact age of the broods was included in the model as a covariate to correct for any differences in age between the moors. The distribution of exact ages within the 4 day and 10 day old broods did not differ systematically between the moors. Mean brood body mass at 4 days and 10 days was significantly higher on Drumochter than on Ralia (Table 3). Analyses of both mean brood body mass and wing length at 10 days (but not at 4 days) showed significant interactions between exact age and moor, suggesting different growth rates on the two moors. After correcting for exact age, broods on Drumochter weighed on average 3.9g more than those on Ralia at 4 days old and $5.7 \mathrm{~g}$ more than those on Ralia at 10 days old. Mean wing length showed a similar pattern (Table 3), with broods on Drumochter having an average wing length approximately 6.1mm longer at 4 days, and 5.6mm longer at 10 days than those on Ralia.

Table 3 here

For 15 broods (Drumochter $n=7$, Ralia $n=8$ ) the relationship between dietary invertebrates and mean brood body mass at 4 days and 10 days was investigated. Moor, and a moor-dietary invertebrate interaction were also included in this analysis. At both 4 days and 10 days mean brood body mass increased significantly with invertebrate numbers (4 days: $F_{1,13}=10.52, P<0.01, \mathrm{R}^{2}=44.7 \%$, Fig. 2; 10 days: $F_{1,13}=5.59, P<0.05, \mathrm{R}^{2}=30.1 \%$;).

Fig. 2 here 


\section{Chick survival and invertebrate abundance}

A total of 42 broods (Drumochter $n=22$, Ralia $n=20$ ) provided data on diet at around 10 days of age together with the proportion of each brood surviving from hatching to 10 days. Moor, and a moor-dietary invertebrate interaction were also included in this analysis. A significantly higher percentage of chicks survived from broods on Drumochter (median: 71\%, Q1-Q3: 50 88) than those on Ralia (57\%, Q1-Q3: $43-71)\left(F_{1,40}=5.98, P<0.05\right)$. Neither invertebrate numbers or the interaction between moor and invertebrate numbers had a significant relationship with brood survival. However, an analysis to investigate the relationship between body mass and survival showed that mean brood body mass at 4 days had a significant positive relationship with the proportion of the brood surviving from hatching to 4 days $\left(F_{1,31}\right.$ $=9.08, P<0.01)$. In this analysis $22.7 \%$ of the variance in proportion of brood surviving was due to mean brood body mass. An outlier with a standardised residual of 2.69 was removed for this analysis, although there was still a significant effect of weight on survival with the outlier included. Moor was included in the starting model but was not significant. There was a similar relationship between body mass and survival at 10 days $\left(F_{1,32}=4.59, P<0.05 ; \mathrm{R}^{2}=\right.$ 12.5). Again, moor was not significant in this analysis.

There was a positive correlation between the numbers of invertebrates in the faeces (per 100 heather bracts) and those sampled by sweep netting $\left(F_{1,15}=5.31, P<0.05\right)$. Neither moor or the interaction between moor and invertebrate availability were significant.

\section{Home range and survival}

Home range area and brood survival was calculated for 17 broods on Drumochter and four on Ralia. Broods in which all the chicks survived between four and ten days old had home range sizes $(0.2 \pm$ $0.02 \mathrm{ha})$ approximately half that of broods in which some of the chicks died during this period (0.1 \pm 
0.02 ha) $\left(T_{16}=3.93, P<0.01\right.$; Fig. 3). Due to the small sample sizes it was not possible to test for differences in home range area between the two moors.

Fig. 3 here

\section{Chick growth and survival: experimental data}

All of the six chicks in the dietary group (one) consisting of only heather progressively lost weight over the duration of the experiment, and none survived past the fifth day after hatching (Fig. 4). Four out of ten of the chicks in the limited invertebrate dietary group (two) died after six to nine days, and all of the three chicks in the unlimited invertebrate dietary group (three) were still alive after ten days. Sample sizes were insufficient to statistically test for differences in survival between the three groups. A repeated-measures ANOVA was used to investigate the effect of invertebrates on chick body mass between day three and ten after hatching: six chicks in group two, and three chicks in group three. Chick age and dietary group had a significant effect on chick body mass $\left(F_{7,49}=59.30\right.$, $P<0.0001 ; F_{1,7}=7.17, P<0.05$ respectively). There was also a significant interaction between day and dietary group $\left(F_{7,49}=3.27, P<0.01\right)$ indicating that the growth rate between the two groups differed, with chicks in the unlimited invertebrate dietary group gaining weight at a faster rate than those in the limited invertebrate group (Fig. 4).

Fig. 4 here

\section{DISCUSSION}

The two study sites represented extremes of the observed range of chick survival rates found on managed red grouse moors in Scotland. July counts on Drumochter record the second highest mean brood sizes from a larger sample of 35 moors, Ralia produced the ninth lowest. Although Ralia 
contained a lower density of birds, clutch size was not significantly different from Drumochter and there were no differences in nest success or egg hatchability. The smaller brood sizes on Ralia observed during July counts appear to be due to poor chick survival. The observed clutch sizes and proportion of eggs hatching together with the observed mean July brood sizes from the counts suggest chick survival rates of $81.3 \%$ and $47.3 \%$ for Drumochter and Ralia respectively. This compares well to survival in broods of radiotagged females of $71 \%$ on Drumochter and $57 \%$ on Ralia. Adult birds on Drumochter contained higher numbers of T. tenuis than birds on Ralia. However, mean burdens on neither moor approached the level (3000 per bird) that has been identified as being related to a reduction in red grouse condition in populations from northern England (Hudson, 1986a). It is, therefore, unlikely that T. tenuis played a significant role in maternal condition or, indirectly, chick survival on these moors, or that this parasite was the cause of chick survival differences between the areas. Ticks were present on Ralia and not found on Drumochter but evidence of louping ill was not recorded. Although hen harriers have been observed on both moors, sightings were infrequent during the main years of this study and it is unlikely that they would have contributed to the difference in chick survival between the two moors. Consequently, we consider it reasonable to exclude $T$. tenuis, louping ill or predation by hen harriers from our considerations. We were not able to compare body mass of hens at capture for radiotelemetry between the moors as birds on Ralia were typically captured in late autumn compared to late winter on Drumochter. However, we compared the body mass of adult females shot on Ralia and Drumochter after the breeding season and found no significant differences. In addition, there were no differences in nest success, clutch size or egg hatchability. These observations do not support the hypothesis that relatively poor maternal nutrition is the cause of poor chick survival on Ralia compared to Drumochter.

\section{Red grouse chick diet}


Heather was the dominant food item in this study, occurring in all faecal samples as has been recorded elsewhere (Grimshaw, 1911; Lance \& Mahon, 1975; Savory, 1977; Hudson, 1986a). Savory (1977) compared the nutrient content of shoots from chick crops with those collected by hand from the areas where the chicks were feeding. He demonstrated strong selection for tips rich in Nitrogen, Phosphorus and Calcium. The regular occurrence of moss capsules in this study also conforms with previous work and these items are thought to provide a readily digestible source of protein for young chicks (Savory, 1977). Any analyses of diet using faeces will inevitably be biased towards material which have identifiable, indigestible parts. Plant or animal material that consists of soft, digestible parts or is hard to identify may be overlooked, so percentages of occurrence in faeces should be interpreted with caution. For example, Tipulids are soft bodied and easier to digest than hard bodied invertebrates such as Coleoptera (Green, 1984). It is likely, therefore, that we are underestimating the number of Tipulids eaten by grouse chicks and as a consequence underestimating the importance these invertebrates in grouse chick diet. Since there is no reason that different invertebrate species should differ in digestibility between the two moors our comparisons are valid, although the magnitude of the differences for some groups will be underestimated. The positive correlation between numbers of invertebrates in faeces with numbers sampled by sweep netting indicates that the diet analysis reflects the invertebrate availability (with respect to numbers) on the two moors. Heather flower remains or heather seed, representing the previous years growth, occurred in 50\% of the samples. We suspect that heather seed was readily digested by young chicks as broken seed capsules were frequently found in the droppings and that we are likely to have underestimated the occurrence of these items in the diet. It has been suggested that improved heather growth and flowering in the previous season may indirectly influence chick survival through improved maternal nutrition prior to breeding (Jenkins et al., 1963, 1967; Moss et al., 1975, 1981, 1993). Alternatively, it may directly 
influence chick survival through improved nutrition as heather flowers and seeds were common food items, or it may lead to increased invertebrate densities with similar benefits. There are some limited data on heather quality on the two moors from this study (Game Conservancy Trust, unpublished data) in the form of percentage phosphorous and nitrogen content. These were taken from two sites on each moor in 1997. Heather from Drumochter contained a slightly higher percentage of phosphorous (Drumochter $=0.07 \%$, Ralia $=0.06 \%$ ) and nitrogen (Drumochter $=1.2 \%$, Ralia $=0.09 \%$ ) than did samples from Ralia. Whether these differences are of sufficient magnitude to influence chick survival through improved nutrition or differential invertebrate densities is, at present, unclear.

Savory (1977) identified invertebrates obtained from crop samples of 2-3 week old red grouse chicks in N.E Scotland. He found a large predominance (89.1\% by number) of Diptera amongst the animal material eaten. Grimshaw (1911) also notes red grouse chicks consuming large numbers of this species. This is comparable to the results from Drumochter where Diptera again predominated (96.5\%), largely comprising Tipulidae (72.9\%). On Ralia a wider range of invertebrates were taken and no one group predominated: Tipulids, comprising 20\% of the identified invertebrates, Curculionids, Staphylinids and larval Symphyta were the most common. Droppings from Ralia contained significantly fewer invertebrates per 100 heather bracts than did those from Drumochter. Savory (1977) compared the availability of invertebrates and chick diet between topogenous boggy flushes, ombrogenous blanket bog and drier heath. Invertebrate availability and the occurrence of invertebrates in chick diet was highest on the boggy flush areas, intermediate on the blanket bog and lowest on the drier areas, largely due to differences in the numbers of Tipulids. This would support the differences found between Ralia, a dry heath, and Drumochter with its mixture of topogenous and ombrogenous areas. 


\section{Chick survival, growth rates and invertebrate abundance}

There were significant differences in mean brood body mass and wing lengths at 4 and 10 days of age between the two moors. Chicks on Drumochter appeared to grow faster then those on Ralia. There were positive correlations between mean brood body mass both at 4 and 10 days and the numbers of invertebrates in the diet. There were also positive correlations between mean brood body mass both at 4 and 10 days and the proportion of the brood surviving to these ages. The effect of moor was not significant in these analyses indicating that chick survival is lower on Ralia because of the reduced growth rate. Hudson (1986a) identified a similar relationship from broods in Yorkshire with broods of chicks eating relatively large quantities of invertebrates weighing more than those eating few. By experimentally testing the relationship between chick diet and body mass we have shown that captive red grouse chicks fed only heather lost weight between the ages of 1 and 5 days. Chicks provided with an unlimited supply of invertebrates were significantly heavier and had faster growth rates than those with a smaller component of invertebrates in their diet.

Broods in which all chicks survived (4-10 days) had smaller home ranges than broods in which some chicks died over this period. Similar relationships between home range size, invertebrate abundance and brood survival have been demonstrated for other galliforms (Hill, 1985; Rands, 1985; Potts, 1986; Hill \& Robertson, 1988) together with experimental manipulations of invertebrate abundance leading to increased survival and decreased home range size (Rands, 1985).

In this study we have demonstrated that there is a positive correlation between the dietary invertebrate and body mass, and also between body mass and chick survival. Broods on Drumochter had a higher invertebrate component in their diet and a faster growth rate, which in turn results in a higher proportion of chick survival, than those on Ralia. We have also shown experimentally that there is a direct causal effect of dietary invertebrates upon chick body mass and growth rate, and that 
chicks fed only heather did not survive under controlled conditions. As such we conclude that chick survival and growth rates are related to the invertebrate component of the chick's diet.

\section{Historical changes in red grouse populations}

Historically, Ralia has produced large numbers of red grouse. MacPherson (1914) reports it as one of the best shooting moors in the region, producing 4025 birds shot in the 1913 season. Over the period 1979-1994 the average yield was 21 birds per season. It would appear that poor chick survival is one possible cause for the low numbers found on Ralia although it is unlikely that this was a problem in the past. Although a proportion of managed red grouse moors exhibit low rates of chick survival, this is not a universal problem and its role in declining red grouse numbers remains uncertain. In this paper we describe the likely role of invertebrates in relation to low chick survival on one moor; other causes such as predation and disease may be of greater importance in reducing chick survival rates

on other moors. That Tipulids occurred in a high proportion of the faecal samples but were relatively scarce in the sweep netting samples may indicate that this sampling method does not accurately reflect Tipulid availability on the two moors. Nevertheless, it would appear that Diptera, particularly Tipulids, do not occur in such large numbers (or percentage frequency) in faecal samples from Ralia as they do in samples from Drumochter and from other studies in Scotland (Grimshaw, 1911;

Savory, 1977). There is anecdotal evidence for declines in Tipulid numbers on a neighbouring moor to Ralia which also appears to suffer low chick survival. Although unquantified, Ralia and the neighbouring moor have apparently become drier in recent decades, possibly due to hill drainage or a falling water table; there is anecdotal evidence of bogs drying out and of associated changes in the vegetation over this period. An investigation into Tipulid abundance in relation to soil moisture and experimental manipulations of water levels is needed to determine the direct effects on invertebrate abundance, chick diet and survival. 


\section{Management recommendations}

There is evidence that increased grazing pressure in upland dwarf shrub communities leads to a reduced invertebrate biomass (Baines, Sage \& Baines, 1994; Fuller \& Gough, 1999). Little is known, however, regarding the mechanisms driving such an effect. Similarly, gross differences in invertebrate abundance have been recorded between different vegetation and soil types (Savory, 1977) although again the mechanisms are poorly understood. The abundance of preferred chick food items is known to be high in wet areas of moorland, particularly around bog flushes (Hudson, 1986a). We suggest that decreasing grazing pressure together with the creation of wet areas within drier moorland types, possibly through the blockage of drains, would be beneficial to red grouse chick survival on certain moors (Hudson \& Newborn, 1995).

\section{ACKNOWLEDGEMENTS}

We would like to thank John and Eira Drysdale and Lord Peel for allowing us access to their land during this study. Financial support was provided by the Scottish Trustees and the Game Conservancy Trust. Thanks to Tim Benton and Kate Buchanan for useful comments on an earlier draft of this manuscript.

\section{REFERENCES}

Baines, D., Sage, R.B. \& Baines, M.M. (1994). The implications of red deer grazing to ground vegetation and invertebrate communities of Scottish native pine woods. J. Appl. Ecol. 31: 776-783

Butterfield J. \& Coulson J.C. (1975). Insect food of adult red grouse. J. Anim. Ecol. 44: 601-608.

Fuller, R.J. \& Gough, S.J. (1999). Changes in sheep numbers in Britain: Implications for bird populations. Biol. Conserv. 91: 73-89.

Green, R. (1984). The feeding ecology and survival of partridge chicks (Alectoris rufa and Perdix perdix) on arable farmland in East Anglia. J. Appl. Ecol. 21: 817-830. 
Grimshaw, P.H. (1911). Food of the red grouse. II. The insect food of young grouse chicks based on an examination of crops and gizzards. In The grouse in health and disease: Being the final report of the committee of inquiry on grouse disease. pp. 88-92. Lord Lovat (Ed.). London: Smith \& Elder.

Hill, D.A. (1985). The feeding ecology and survival of pheasant chicks on arable farmland. J. Appl. Ecol. 22: 645-654.

Hill, D.A. \& Robertson, P.A. (1988). The pheasant: ecology, management and conservation. Oxford: Blackwell.

Hudson, P.J. (1986a). Red grouse: the biology and management of a wild gamebird. Fordingbridge: The Game Conservancy Trust.

Hudson, P.J. (1986b). The effect of a parasitic nematode on the breeding production of red grouse. $J$. Anim. Ecol. 55: 85-94

Hudson, P.J. (1992). Grouse in space and time: the population biology of a managed gamebird. Fordingbridge: The Game Conservancy Trust.

Hudson, P.J. \& Newborn, D. (1995). A manual of red grouse and moorland management. Fordingbridge: The Game Conservancy Trust.

Hudson, P.J., Norman, R., Laurenson, M.K., Newborn, D., Gaunt, M., Jones, L., Reid, H., Gould, E., Bowers, R. \& Dobson, A. (1997). Persistence and transmission of tick-borne viruses: Ixodes ricinus and louping-ill virus in red grouse populations. Parasitology 111: 49-58.

Jenkins, D., Watson, A. \& Miller G.R. (1963). Population studies of red grouse in north-east Scotland. J. Anim. Ecol. 1: 183-195.

Jenkins, D., Watson, A. \& Miller G.R. (1967). Population fluctuations in red grouse. J. Anim. Ecol. 36: $97-122$

Jennrich, R.J \& Turner, F.B. (1969). Measurement of non-circular home range. J. Theor. Biol. 22: 227-237. 
Lance, A.N \& Mahon G. (1975). Foods of a marginal red grouse population in western Ireland. Wildl. Mgmt. 39: 183-187.

MacPherson, H.B. (1914). Grouse in Badenoch. The Field 23: 181.

Moss, R., Watson, A. \& Parr, R.A. (1975). Maternal nutrition and breeding success in red grouse. J. Anim. Ecol. 44: 233-244.

Moss, R., Watson, A., Rothery, P. \& Glennie, W.W. (1981). Clutch size, egg size, hatch weight and laying date in relation to early mortality in red grouse chicks. Ibis 123: 450-462.

Moss, R. \& Watson, A. (1985). Adaptive value of spacing behaviour in population cycles of Red Grouse and other animals. In Behavioural Ecology: 275-294. Sibley, R.M. \& Smith, R.H. (Eds). London: Blackwell.

Moss, R., Watson, A., Parr, R.A., Trenholm, I.B. \& Marquiss, M. (1993). Growth rate, condition and survival of red grouse Lagopus lagopus scoticus chicks. Ornis Scan. 24: 303-310.

Potts, G.R. (1986). The partridge: pesticides, predation and conservation. London: Collins.

Pullianen, E. \& Eskonen, H. (1982). Chemical composition of plant matter eaten by young chicks of the willow grouse Lagopus lagopus in northern Finland. Ornis Fenn. 59: 146-148.

Rands, M.R.W. (1985). Pesticide use on cereals and the survival of grey partridge chicks: a field experiment. J. Appl. Ecol. 22: 49-54.

Redpath, S.M. (1991). The impact of hen harriers on red grouse breeding success. J. Appl. Ecol. 28: 659-671.

Redpath, S.M. \& Thirgood, S.J. (1997). Birds of prey and red grouse. London: HMSO.

Robertson, P.A., Aebischer, N.J., Kenward, R.E., Hanski, I.P. \& Williams, N.P. (1998). Simulation and jack-knifing assessment of home-range indices based on underlying trajectories. J. Appl. Ecol. 35: 928-940.

Savory, C.J. (1977). The food of red grouse chicks Lagopus l. scoticus. Ibis 119: 1-9. 
Southwood, T.R.E \& Cross, D.J. (1969). The ecology of the partridge III: breeding success and the abundance of insects in natural habitats. J. Anim. Ecol. 38: 497-509.

Thirgood, S.J., Redpath, S.M., Hudson, P.J., Hurley, M.M. \& Aebischer, N.J. (1995). Effects of necklace radio transmitters on survival and breeding success of Red Grouse Lagopus lagopus scoticus. Wildl. Biol. 1: 121-126.

Thompson, D.B.A., MacDonald, A.J., Marsden, J.H. \& Galbraith, C.A. (1995). Upland heather moorland in Great Britain: a review of international importance, vegetation change and some objectives for nature conservation. Biol. Conserv. 71: 163-178.

Watson, A. \& Moss, R. (1979). Population cycles in the tetraonidae. Ornis Fenn. 56: 87-109. Watson, A., Moss, R., Parr, R., Mountford, M.D. \& Rothery, P. (1994). Kin landownership, differential aggression between kin and non-kin, and population fluctuations in red grouse. J. Anim. Ecol. 63: 39-50.

Wilson, J.D., Morris, A.J., Arroyo, B.E., Clark, S.C. \& Bradbury, R.B. (1999). A review of the abundance and diversity of invertebrate and plant foods of granivorous birds in northern Europe in relation to agricultural change. Agric. Ecosyst \& Environs. 75: 13-30. 
Table 1

General Linear Models for numbers of grouse per $\mathrm{km}^{2}$ in April and July, numbers of broods, clutch and brood sizes on Drumochter and Ralia. There were insufficient degrees of freedom to include an interaction between year and moor for analyses on the number of grouse in April and July and the number of broods. Year was constrained into these analyses regardless of its significance.

\begin{tabular}{lccccc}
\hline & $\begin{array}{c}\text { no. of April } \\
\text { adults }\end{array}$ & $\begin{array}{c}\text { no. of July adults } \\
+ \text { young }\end{array}$ & no. of broods & clutch size & July brood size \\
\hline moor & $F_{1,11}=96.59 * * *$ & $F_{1,10}=83.39 * * *$ & $F_{1,10}=43.37 * * *$ & - & $F_{1,10}=38.30^{* * *}$ \\
year & $F_{11,11}=2.64$ & $F_{10,10}=4.43^{*}$ & $F_{10,10}=2.59$ & $F_{10,232}=6.28 * * *$ & $F_{10,10}=4.54 *$ \\
\hline
\end{tabular}


Table 2.

Red grouse chick diet on two moors in Scotland ascertained through faecal analysis. The number and percentage of faecal samples containing each item are presented together with the numerical range of individual items per faecal sample where present.

\begin{tabular}{lccccccccc}
\hline & \multicolumn{3}{c}{ Overall (n=62) } & \multicolumn{2}{c}{ Ralia (n=22) } & \multicolumn{2}{c}{ Drumochter(n=40) } \\
Item & $\mathbf{n}$ & $\mathbf{\%}$ & range & $\mathbf{n}$ & $\mathbf{\%}$ & range & $\mathbf{n}$ & \% & range \\
\hline Heather Bracts & 62 & 100.0 & $23-5600$ & 22 & 100.0 & $23-5600$ & 40 & 100.0 & $26-4000$ \\
Tipulidae & 54 & 87.1 & $1-142$ & 15 & 68.2 & $1-6$ & 39 & 97.5 & $1-142$ \\
Moss capsule & 32 & 51.6 & $1-155$ & 8 & 36.4 & $1-42$ & 24 & 60.0 & $1-155$ \\
Sundew Heads & 30 & 48.4 & $1-146$ & 5 & 22.7 & $2-94$ & 25 & 62.5 & $1-146$ \\
Heather Seed & 26 & 41.9 & $1-19$ & 6 & 27.3 & $1-8$ & 20 & 50.0 & $1-19$ \\
Chironomidae & 22 & 35.5 & $1-87$ & 3 & 13.6 & $1-3$ & 19 & 47.5 & $1-87$ \\
Curculionidae & 22 & 35.5 & $1-37$ & 13 & 59.1 & $1-37$ & 9 & 22.5 & $1-4$ \\
Symphata larvae sp. & 15 & 24.2 & $1-5$ & 6 & 27.3 & $1-5$ & 9 & 22.5 & $1-4$ \\
Staphylinidae & 15 & 24.2 & $1-4$ & 9 & 40.9 & $1-3$ & 6 & 15.0 & $1-4$ \\
Heather Hooks & 12 & 19.4 & $1-10$ & 3 & 13.6 & 2 & 9 & 22.5 & $1-10$ \\
Elateridae & 11 & 17.7 & $1-4$ & 6 & 27.3 & 1 & 5 & 12.5 & $1-4$ \\
Ticks & 9 & 14.5 & $1-5$ & 3 & 13.6 & $1-5$ & 6 & 15.0 & $1-3$ \\
Opilionidae & 8 & 12.9 & 1 & 1 & 4.5 & 1 & 7 & 17.5 & 1 \\
Carabidae & 7 & 11.3 & 1 & 5 & 22.7 & 1 & 2 & 5.0 & 1 \\
Aranaidae sp. & 6 & 9.7 & $1-2$ & 3 & 13.6 & $1-2$ & 3 & 7.5 & $1-2$ \\
Carabidae larvae & 5 & 8.1 & $1-2$ & 2 & 9.1 & 1 & 3 & 7.5 & $1-2$ \\
Symphata sp. & 3 & 4.8 & 1 & 1 & 4.5 & 1 & 2 & 5.0 & 1 \\
Formicidae & 2 & 3.2 & 1 & 1 & 4.5 & 1 & 1 & 2.5 & 1 \\
Ichneumonidae & 1 & 1.6 & 1 & 1 & 4.5 & 1 & 0 & 0.0 & - \\
Lepidoptera larvae & 1 & 1.6 & 2 & 0 & 0.0 & - & 1 & 2.5 & 2 \\
\hline & & & & & & & & & \\
\hline & & & & & & & & &
\end{tabular}


Table 3

Mean body mass and winglengths ( \pm s.e.) of broods at 4 days and 10 days, and the results from GLMs testing differences between the two moors. Values presented are corrected for the exact age of the broods. $*=\mathrm{p}<0.05, * *=\mathrm{p}<0.01$.

\section{Drumochter $\quad$ Ralia $\quad$ results from GLM}

\section{mean brood body mass (g)}

4 days

$25.3 \pm 0.6 \quad 21.3 \pm 0.6$

moor: $F_{1,37}=6.01^{*}$

10 days

$42.1 \pm 1.5 \quad 36.6 \pm 2.7$

moor: $F_{1,36}=7.64 *$

age*moor: $F_{1,36}=8.69 * *$

\section{mean brood winglength $(\mathrm{mm})$}

4 days

10 days

$\begin{array}{ll}34.2 \pm 0.8 & 28.1 \pm 1.0 \\ 61.2 \pm 1.7 & 55.6 \pm 2.1\end{array}$

moor $F_{1,37}=6.24 *$

moor $F_{1,36}=4.61 *$

age*moor $F_{1,36}=5.39 *$ 


\section{FIGURE LEGENDS}

Fig. 1.

Observed mean brood sizes from 35 managed red grouse moors in Scotland. A $1 \mathrm{~km}^{2}$ area of each moor was counted using pointing dogs in July for at least five years between 1985-1996.

The two moors examined in detail in this paper are indicated by black shading (Ralia on the left, Drumochter on the right).

Fig. 2.

The relationship between mean brood body mass at 4 days (range 3-6) and the invertebrate component of the chick diet on Drumochter $(\bullet)$ and Ralia (o). The scale on the x-axis has been backtransformed from the original arcsine square root transformation.

Fig. 3

Home range area (hectares) of broods in which all chicks survived between four and ten days old (survival =1), and broods in which some chicks died during this period (survival < 1 ).

Fig. 4

Mean chick body mass in three different dietary treatment groups: heather $(\bullet)$, heather + limited invertebrates $(\nabla)$, and heather + unlimited invertebrates $(\boldsymbol{\square})$. 
Figure 1 (ms 00/53)

Park, Robertson, Campbell, Foster, Russel, Newborn, \& Hudson

Red grouse chick growth and survival

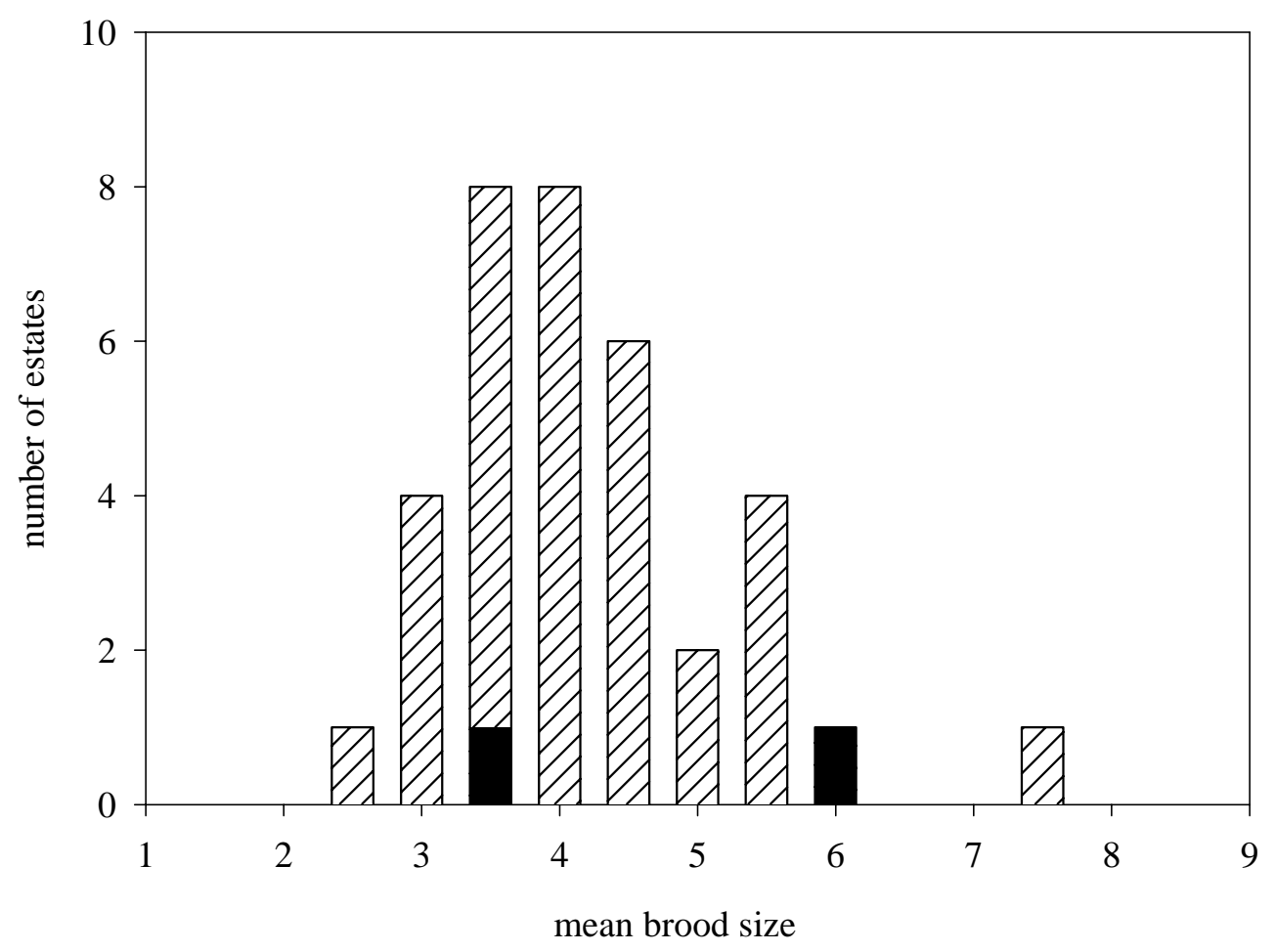


Figure 2 (ms 00/53)

Park, Robertson, Campbell, Foster, Russel, Newborn, \& Hudson

Red grouse chick growth and survival

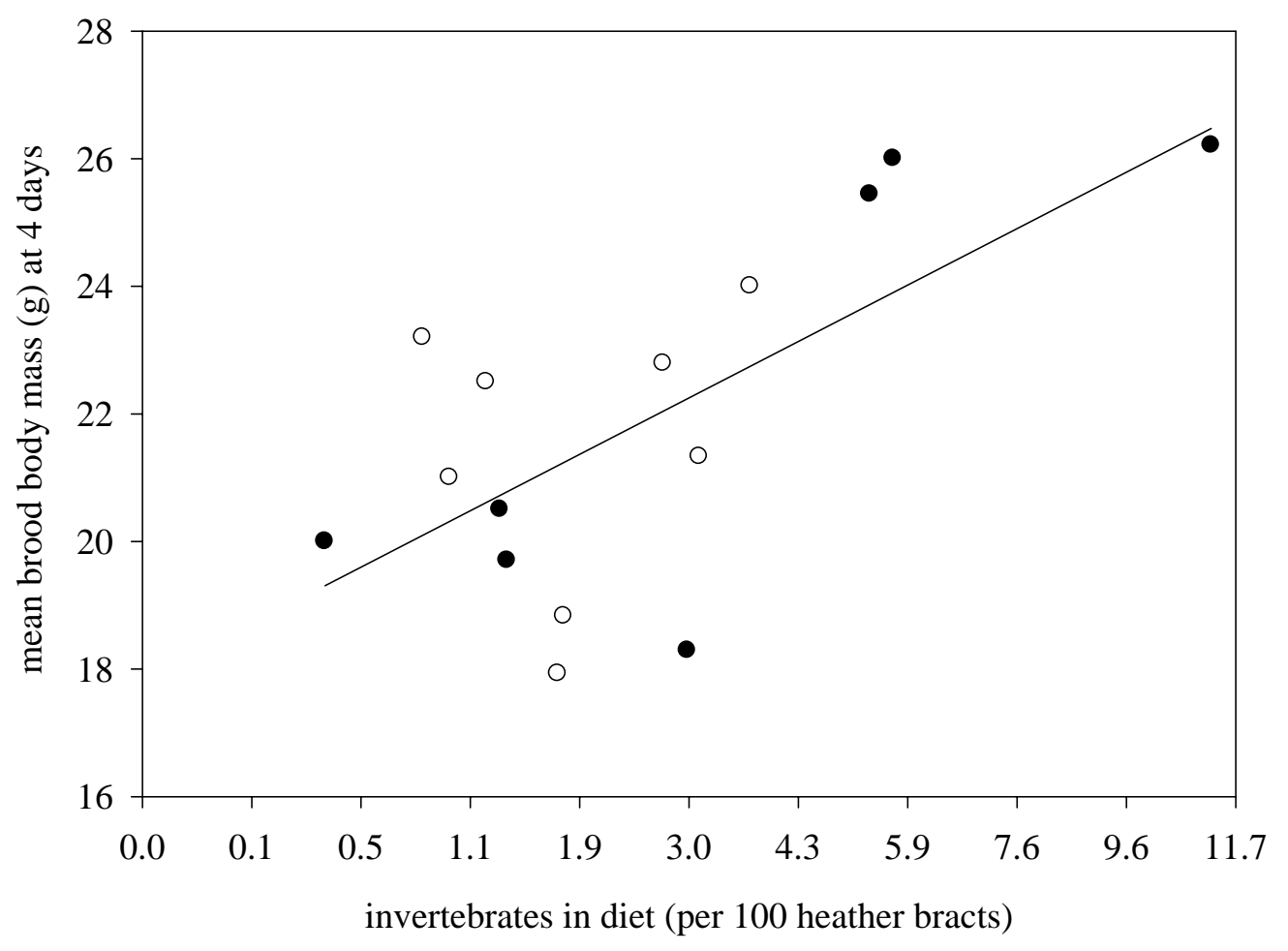


Figure 3 (ms 00/53)

Park, Robertson, Campbell, Foster, Russel, Newborn, \& Hudson

Red grouse chick growth and survival

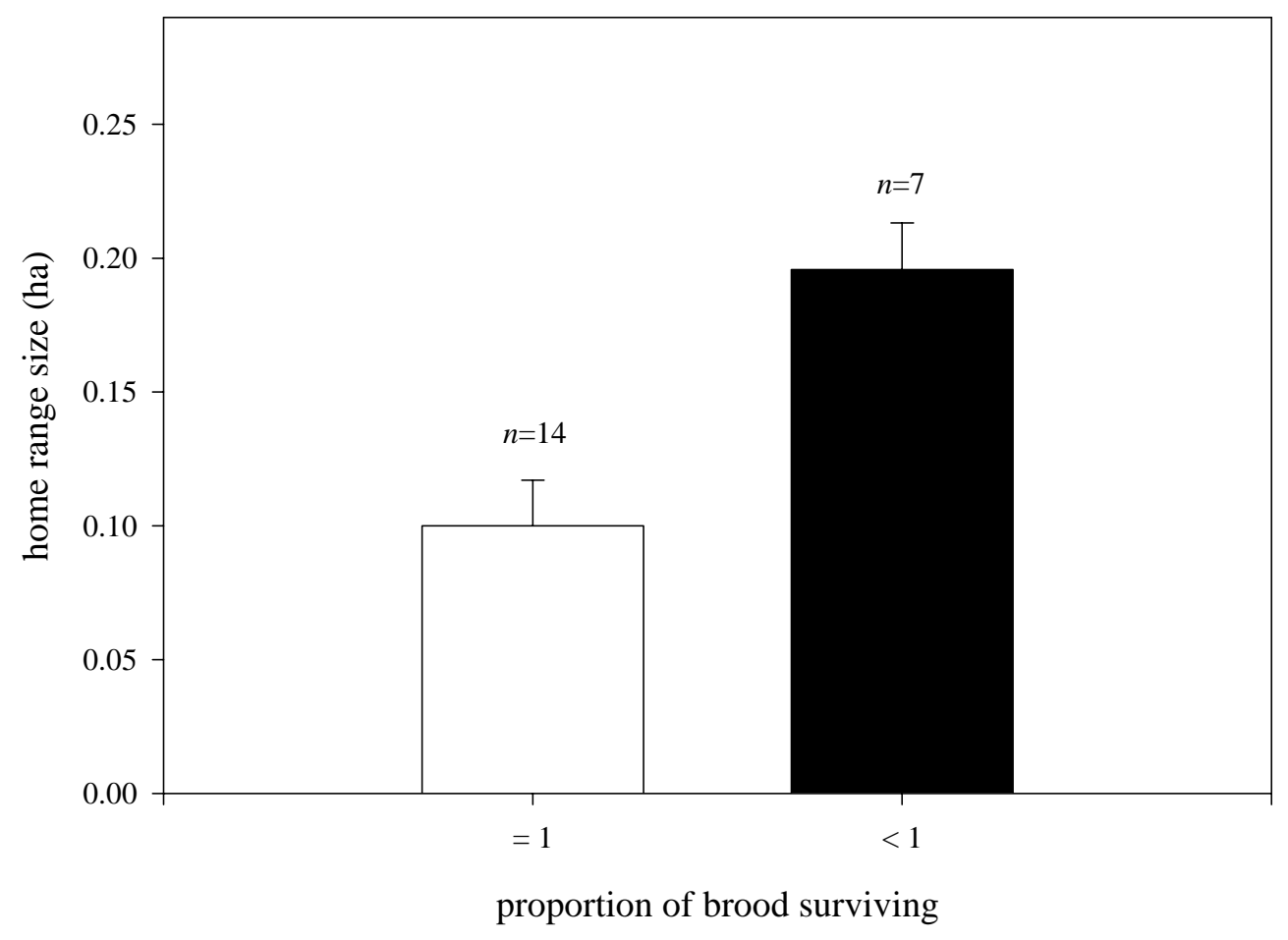


Figure 4 (ms 00/53)

Park, Robertson, Campbell, Foster, Russel, Newborn, \& Hudson

Red grouse chick growth and survival

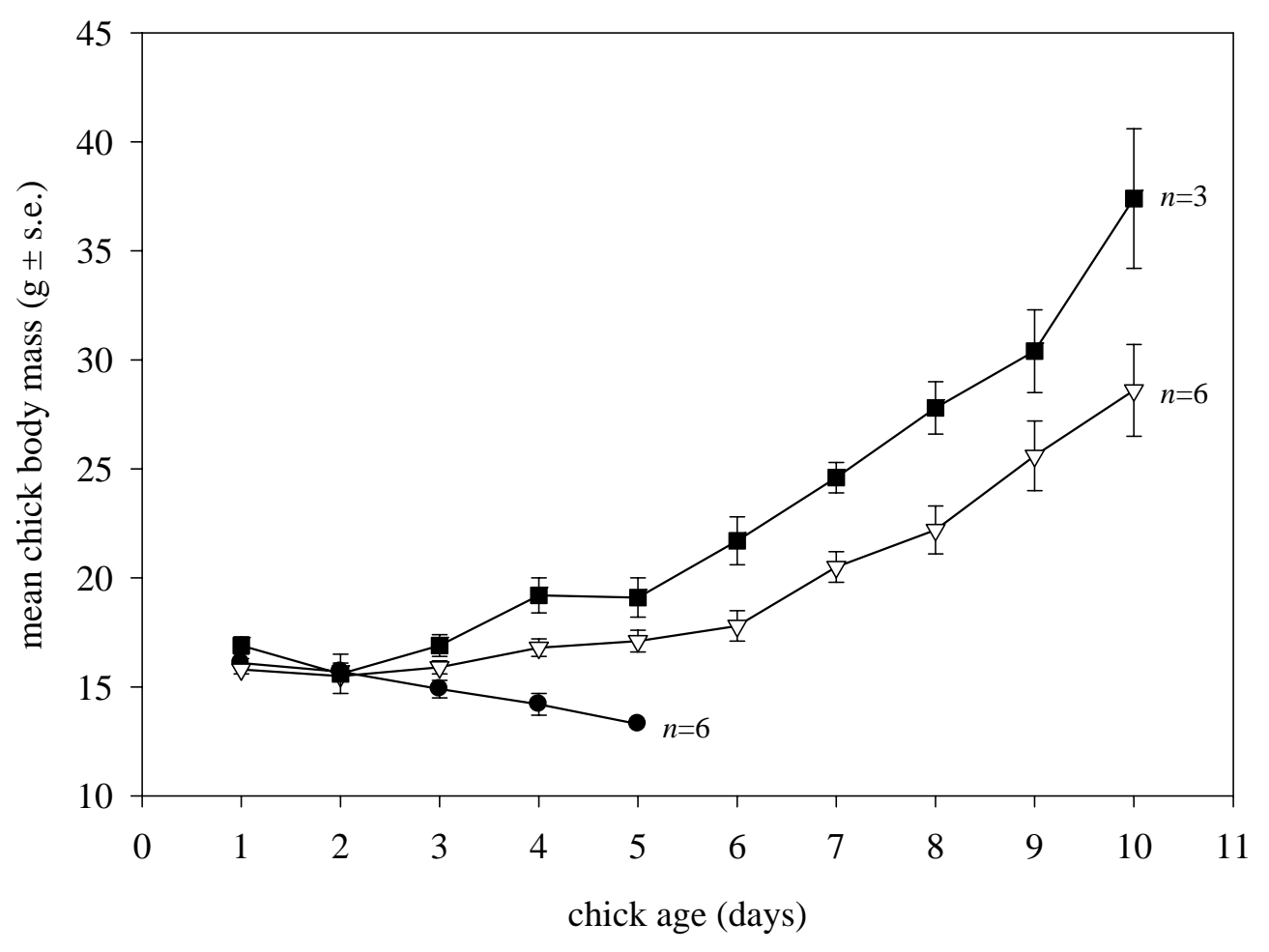

